\title{
Analisis Kesulitan Belajar Siswa dalam Pembelajaran Matematika yang Menggunakan Pendekatan PMRI
}

\author{
Pius E P Cahirati1 ${ }^{1}$ Alberta P Makur ${ }^{2 *}$, dan Sebastianus Fedi ${ }^{3}$ \\ 1,2*3Program Studi Pendidikan Matematika, Unika Santu Paulus Ruteng \\ Jalan Ahmad Yani no 10, Ruteng, NTT, Indonesia \\ 1ekocahirati642@gmail.com, ${ }^{2 * a l b e r t a \_m a k u r @ u n i k a s t p a u l u s . a c . i d, ~}$ \\ ${ }^{3}$ sebastianus_fedi@ unikastpaulus.ac.id
}

Artikel diterima: 07-10-2019, direvisi: 27-05-2020, diterbitkan: 31-05-2020

\begin{abstract}
Abstrak
Penelitian ini bertujuan untuk membahas 1) kesulitan belajar matematika seperti apa yang dialami siswa dalam pembelajaran yang menerapkan PMRI; 2) alasan mengapa siswa mengalami kesulitan belajar matematika dalam Pembelajaran Matematika menggunakan PMRI? Penelitian ini bertujuan untuk mendeskripsikan jenis-jenis kesulitan yang dialami oleh siswa, disertai dengan faktor-faktor yang menyebabkan kesulitan matematika. Penelitian ini adalah penelitian kualitatif deskriptif dengan 23 siswa yang menunjukkan kesulitan dalam belajar matematika. Teknik yang digunakan untuk mengumpulkan data adalah observasi, wawancara, kuesioner, dokumentasi, dan catatan lapangan. Analisis data dilakukan dengan reduksi data, penyajian data, dan penarikan kesimpulan. Hasil dari penelitian ini adalah jenis kesulitan belajar yang dialami siswa, yaitu kesulitan dalam memahami konsep sistem persamaan dua variabel dan tiga variabel, kesulitan menghitung angka dalam sistem persamaan linear untuk dua variabel dan tiga variabel, dan kesulitan memecahkan masalah dalam masalah cerita dalam materi SPLDV dan SPLTV.

Kata Kunci: kesulitan belajar siswa, faktor penyebab kesulitan belajar, PMRI.
\end{abstract}

\section{Analysis of Student Learning Difficulties in Mathematics Learning Using the PMRI Approach}

\begin{abstract}
This research is aimed to discuss 1) what kind of mathematics learning difficulties students experience in PMRI learning; 2) the reasons why students are having difficulty learning mathematics in Mathematics Learning using PMRI? This study aims to describe the types of difficulties experienced by students, accompanied by factors causing mathematical difficulties. This study is a descriptive qualitative study with 23 students who indicated difficulties in learning mathematics. The technique used to collect data is observation, interviews, questionnaires, documentation, and field notes. Data analysis is done by data reduction, data presentation, and conclusion drawing. The results of this study are the types of learning difficulties experienced by students, namely difficulties in understanding the concepts of system of two-variable and threevariable linear equations, difficulties in calculating numbers in a system of linear equations for two variables and three variables, and the difficulty of solving problems in story problems in SPLDV and SPLTV material.

Keywords: Student Learning Difficulties, Learning difficulties Factor, PMRI.
\end{abstract}




\section{Pendahuluan}

Freudenthal (Wijaya, 2012) menyatakan bahwa Matematika adalah sebuah bentuk aktivitas manusia. Untuk itu, sekelompok ahli dari Freudhental Institute-Belanda pada tahun 1971 (Badruddin, 2013), melahirkan sebuah pendekatan pembelajaran yang relevan dengan pemanfaatan hal-hal nyata (Edo \& Samo, 2017) yang dapat dipahami lewat kegiatan yang telah ada di lingkungan siswa. Pendekatan pembelajaran yang dimaksud adalah Realistic Matematic Education (RME) di Indonesia dikenal sebagai Pendidikan Matematika Realistik Indonesia (PMRI).

Pendidikan Matematika Realistik Indonesia (Soviawati, 2011), pada dasarnya adalah pemanfaatan realitas dan lingkungan yang dipahami peserta didik untuk memperlancar proses pembelajaran matematika, sehingga mencapai tujuan pendidikan matematika secara lebih baik. Dalam pembelajaran matematika yang menggunakan PMRI, siswa dituntut untuk mengembangkan sendiri pengetahuannya. Treffers (Wijaya, 2012) menyebutkan beberapa karakteristik dari pembelajaran matematika realistik yaitu: (1) Penggunaan konteks: Pembelajaran diawali dengan masalah kontekstual (dunia nyata) sehingga memungkinkan siswa menggunakan pengalaman sebelumnya secara langsung untuk menemukan suatu konsep. Melalui abstraksi dan formalisasi (Yusri \& Sari, 2017), siswa dapat mengembangkan konsep yang lebih komplit. Kemudian siswa dapat mengaplikasikan konsep matematika ke dalam bidang yang lain ataupun dunia nyata sehingga memperkuat pemahaman konsep; (2) Penggunaan model: Istilah model berkaitan dengan situasi dan model matematika yang dikembangkan sendiri oleh siswa (self-developed models). Selfdeveloped models berperan sebagai jembatan bagi siswa (Afriansyah \& Dahlan, 2017) dari situasi konkret menuju abstrak atau konteks informal ke formal. Siswa membuat model sendiri dalam menyelesaikan masalah sehingga diperoleh pengetahuan matematika formal (bersifat abstrak); (3) Penggunaan hasil konstruksi siswa: Siswa mempunyai kesempatan untuk mengembangkan strategi-strategi informal pemecahan masalah yang dapat mengarah pada konstruksi prosedurprosedur pemecahan masalah. Dengan bimbingan guru, siswa diharapkan menemukan kembali konsep dalam bentuk formal; (4) Interaktivitas: Interaksi antara siswa dan guru merupakan hal mendasar dalam pembelajaran matematika realistik. Secara eksplisit bentuk-bentuk interaksi yang berupa negosiasi, penjelasan, pembenaran, setuju, tidak setuju, pertanyaan atau refleksi digunakan untuk mencapai bentuk formal dari bentukbentuk informal siswa; (5) Keterkaitan unit belajar (intertwinement): Dalam pembelajaran matematika realistic (Nursyahidah, Saputro, Albab, Aisyah, 2020), keterkaitan unit-unit matematika adalah esensial. Dengan keterkaitan ini, 
akan memudahkan siswa dalam proses pemecahan masalah.

Namun, kegiatan belajar tidak selamanya berhasil (Waskitoningtyas, 2011; Sopian \& Afriansyah, 2017) meskipun pendekatan pembelajaran tertentu telah diterapkan. Dalam kegiatan belajar, terkadang siswa mengalami hambatanhambatan yang mengakibatkan kegagalan belajar. Kesulitan belajar matematika menurut Widdiharto (Waskitoningtyas, 2011) adalah kurang berhasilnya siswa dalam menguasai konsep, prinsip, atau algoritma penyelesaian masalah, walaupun telah berusaha mempelajarinya, ditambah lagi dengan kurangnya seorang siswa dalam mengabstraksi, menggeneralisasi, berpikir deduktif dan mengingat konsep-konsep maupun prinsip-prinsip biasanya akan selalu merasa bahwa suatu pelajaran yang diberikan itu sulit. Merujuk pada penelitian Yuni Darjiani (Tyas, 2016) tentang analisis kesulitan-kesulitan belajar Matematika Siswa Kelas $V$ dalam implementasi Kurikulum 2013 di SD Piloting SeKabupaten Gianyar tahun 2014/2015 menunjukan bahwa kesulitan siswa terdapat pada keterempilan berhitung, kesulitan memahami konsep, dan kesulitan dalam pemecahan masalah. Kesulitan ini terjadi karena faktor kesulitan dari dalam individu sendiri saat mempresepsi dan melakukan pemrosesan terhadap obyek yang diinderainya. Faktor kesulitan ini dapat dilihat dari motivasi siswa, usia siswa, jenis kelamin, suasana kegiatan pembelajaran, dan sumber belajar.

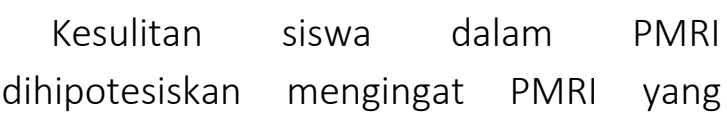
dianggap ideal untuk konteks kekinian justru belum memberikan kontribusi yang memuaskan bagi kualitas matematika Indonesia. Oleh karena itu, diperlukan penelitian terhadap masalah ini untuk mencari tahu bentuk kesulitan belajar matematika siswa dalam pembelajaran matematika yang menggunakan PMRI, disertai faktor penyebab munculnya kesulitan tersebut. Penelitian ini akan dilaksanakan di Kelas X Keuangan 1 SMK Karya Ruteng pada semester ganjil tahun ajaran 2018/2019, dengan subyek penelitian adalah siswa kelas X Keuangan 1. Materi pelajaran yang disajikan dengan PMRI adalah Sistem Persamaan Linear Tiga Variabel. Untuk menjawab penenelitian ini, rumusan masalah penelitian ini adalah (1) Apa saja bentuk kesulitan belajar siswa dalam pembelajaran matematika yang menggunakan PMRI, dan (2) Mengapa kesulitan tersebut bisa terjadi?

\section{Metode}

Jenis penelitian ini adalah Kualitatif deskriptif. Penelitian ini berjenis kualitatif karena fokus pada satu perhatian yaitu kesulitan siswa dalam pembelajaran menggunakan pendekatan PMRI. Metode deskriptif dipakai karena penelitian ini bertujuan untuk membuat gambaran secara sistematis, faktual dan akurat dari fakta-fakta, atau sampel yang diteliti (Sugiyono, 2012) 
Penelitian ini dilaksanakan pada bulan November sampai dengan Desember 2018 di SMK Karya Ruteng, Kabupaten Manggarai, NTT. Subyek penelitian adalah siswa kelas $X$ Keuangan 1 SMK Karya Ruteng. Dalam penelitian ini, instrumen penelitian berupa lembar observasi, angket, lembar wawancara, dokumentasi, dan catatan lapangan. Lembar observasi dibuat terhadap guru dan juga terhadap siswa dengan jawaban 'Ya' atau 'Tidak'. Lembar observasi terhadap guru dibuat untuk mengukur keefektifan pembelajaran matematika menggunakan pendekatan PMRI yang dilaksanakan oleh guru. Sedangkan observasi terhadap siswa dibuat untuk mengukur tingkat keaktifan peserta didik dalam pembelajaran matematika yang dibawakan dengan menggunakan pendekatan PMRI. Kedua lembar observasi didukung juga oleh catatan lapangan yang menulis setiap kejadian yang terjadi dalam pembelajaran dan juga dokumentasi berupa foto saat kegiatan pembelajaran sedang berlangsung. Insturmen yang kedua adalah angket. Angket dibuat untuk melihat bentuk kesulitan belajar matematika berdasarkan cakupan studi matematika yang dikemukakan oleh Jemaris (dalam Tyas: 2016) bahwa matematika hendaknya mencakup tiga elemen yaitu konsep, keterampilan, dan pemecahan masalah. Ketiga jenis kesulitan siswa ini didukung tingkat kebenarannya oleh dokumentasi terhadap hasil pekerjaan siswa yang dikerjakan dan kemudian dikumpulkan pada akhir pembelajaran. Angket diukur dengan menggunakan skala likert. Instrumen yang ketiga adalah wawancara. Wawancara dibuat untuk mengkaji lebih dalam terkait bentuk kesulitan belajar dalam langkah-langkah pembelajaran disertai faktor penyebabnya. Dalam penelitian ini, analisis data hasil observasi hasil angket, dan wawancara siswa dilakukan dengan menggunakan langkahlangkah menurut Miles dan Huberman (Tyas, 2016) yakni reduksi data, penyajian data dan penarikan kesimpulan.

\section{Hasil dan Pembahasan}

Penelitian ini dilakukan untuk mendeskripsikan kesulitan yang dialami siswa saat proses pembelajaran menggunakan pendekatan PMRI dalam materi Sistem Persamaan Linear.

\section{A. Kesulitan dalam diri siswa.}

Dalam dua pembelajaran yang telah berlangsung, sebelum memulai pembelajaran, guru mengecek kehadiran siswa. Dalam dua pertemuan yang telah dijadwalkan, terdapat 7 dari 30 siswa yang tidak hadir dengan alasan sakit. Ketidakhadiran siswa tersebut berdampak pada tertinggalnya materi pelajaran. Melihat hal tersebut, faktor kesehatan perlu menjadi perhatian mengingat dalam PMRI siswa tidak hanya ditambah pengetahuannya melainkan juga penanaman nilai sosial melalui diskusi ataupun latihan mengkomunikasikan gagasan melalui presentasi.

Selain itu, sikap positif terhadap suatu mata pelajaran adalah awal yang baik untuk 
proses pembelajaran. Sebaliknya sikap negatif terhadap mata pelajaran akan berpotensi menimbulkan kesulitan belajar atau membuat hasil belajar yang kurang maksimal. Berdasarkan hasil wawancara, semua siswa yang diwawancarai menyenangi pembelajaran matematika. Akan tetapi, ditemukan 2 siswa yang menyukai pembelajaran matematika dengan syarat. Dari pernyataan siswa S-3 dalam hasil wawancara, siswa tidak menyukai pelajaran matematika ketika guru tidak mengangkat masalah kontekstual. Sedangkan siswa S-1 akan lebih menyukai pembelajaran matematika apabila menggunakan masalah kontekstual.

Sikap siswa pada pembelajaran matematika dipengaruhi oleh strategi guru yang mengajar khususnya dalam mengangkat masalah kontekstual. Menurut Van de Henvel-Panhuizen (Soviawati, 2011), bila anak belajar matematika terpisah dari pengalaman mereka sehari-hari maka anak akan cepat lupa dan tidak dapat mengaplikasikan matematika. Dalam sumber yang sama, Zamroni mengungkapkan bahwa mengaitkan pengalaman kehidupan nyata anak dengan ide-ide matematika dalam pembelajaran di kelas penting dilakukan agar pembelajaran bermakna. Ketika siswa menunjukan sikap positif dalam pembelajaran yang mengangkat masalah kontekstual maka siswa menerima pembelajaran yang menggunakan PMRI mengingat PMRI adalah sebuah pendekatan yang mengangkat masalah kontekstual dalam implementasinya.

\section{B. Kesulitan pada saat Apersepsi}

Berdasarkan hasil observasi, kegiatan apersepsi tidak berjalan efektif. Ketidakefektivan terjadi karena siswa tidak menjawab pertanyaan guru karena telah lupa terhadap materi yang menjadi fondasi ataupun yang berkaitan dengan SPLDV ataupun SPLTV. Hasil wawancara menunjukkan bahwa motivasi belajar siswa S-5 dan siswa S-6, rendah. Hal itu ditandai dengan siswa S-5 dan siswa S-6 yang tidak mempelajari kembali materi yang telah diajarkan disekolah ketika di rumah. Siswa S-5 hanya belajar ketika ada tugas dari guru, sedangkan siswa S-6 hanya sibuk bermedia sosial. Rendahnya motivasi siswa juga mengakibatkan siswa tidak antusias mengikuti pembelajaran matematika sehingga menimbulkan kesulitan belajar matematika. Berdasarkan skor pada angket, siswa S-5 dan siswa S-6 merupakan siswa yang paling banyak mengalami kesulitan belajar.

Motivasi adalah suatu yang penting bagi siswa. Siswa dengan motivasi belajar yang rendah akan kesulitan memperoleh nilai yang lebih tinggi dari siswa yang memiliki motivasi belajar yang kuat. Hal tersebut senada dengan hasil pernelitian Hayati (2016) bahwa siswa yang aktif dan rutin dalam belajar di sekolah maupun di rumah jelas akan membawa dampak yang baik pada hasil belajarnya, karena dengan kebiasaan belajar yang baik dan tinggi atau belajar yang rutin dan efektif, pemahaman 
dari sejumlah materi pembelajaran yang disampaikan akan meningkat. Bila pemahaman meningkat, maka hasil belajar yang dipeoleh pun juga akan meningkat. Hal ini menyebabkan beban yang harus dipelajarinya banyak sedangkan waktu belajar sedikit. Karena waktu belajar yang tidak teratur atau kebiasaan belajarnya yang kurang baik, siswa akan menemukan kesulitan-kesulitan, yang kemudian kesulitan-kesulitan tersebut menjadi satu dan menumpuk menjadi beban bagi siswa.

Dalam PMRI, pengetahuan dibuat dari hasil konstruksi pengalaman belajar siswa. Dengan demikian, pembelajaran berpusat pada siswa. Oleh karena itu, motivasi sangat diperlukan dalam diri siswa agar kesulitan belajar dalam pembelajaran dapat terhindarkan.

\section{Kesulitan dalam Permainan}

Media merupakan sarana untuk menyampaikan informasi agar siswa lebih mudah memahami materi yang diajarkan. Media yang digunakan dalam pembelajaran berupa kartu umur siswa, uang mainan, barang jualan seperti buku, pensil, dan balpoin.Ini merupakan benda konkrit. Penggunaan media konkrit dalam pembelajaran diperlukan karena dalam pembelajaran, masih terdapat siswa yang kesulitan berpikir secara abstrak. Menurut Heruman (Tyas, 2016) penggunaan media konkret dalam pembelajaran sangatlah penting bagi siswa belum bisa berpikir secara abstrak. Media yang digunakan guru adalah media yang ada di sekitar siswa. Benda-benda tersebut dijadikan bahan praktik untuk siswa. Akan tetapi, ketika memperagakan atau menggunakan media, haruslah mengunakan petunjuk seperti yang dikatakan siswa S-6 dan siswa S-1 dalam wawancara.

Dalam pembelajaran yang telah berlangsung, guru membagi peran kepada masing-masing siswa dan kemudian membacakan narasi. Terdapat satu siswa yang bertugas menuliskan pertanyaan di papan tulis. Guru tidak menulis metode pemecahan ataupun catatan lain, dengan alasan agar siswa menemukan sendiri berdasarkan pengetahuan yang dimiliki siswa. Dari hal tersebut dapat dilihat bahwa, ketidakmampuan siswa menjawab pertanyaan pada akhir permainan disebabkan oleh kurangnya pengetahuan awal siswa untuk materi SPLDV dan SPLTV.

\section{Kesulitan Memahami Konsep}

Dalam penelitian ini, kesulitan memahami konsep yang dialami siswa meliputi kesulitan pada memahami masalah kontekstual dan kesulitan membuat model matematika. Berdasarkan hasil rekapitulasi, siswa yang kesulitan memahami masalah kontekstual pada materi SPLDV sebanyak 3 siswa dan pada materi SPLTV sebanyak 4 siswa dari total 23 siswa yang mengisi angket. Kesulitan memahami masalah kontekstual yang dialami siswa ditandai dengan ketidakmampuan membedakan besaran variabel berdasarkan petunjuk dalam soal cerita, untuk mencari tahu umur kakak dan adik. Siswa kesulitan memahami soal yang diberikan dengan salah membuat 
pemisalan terhadap permasalahan yang ada.

Triyas (Sulistiyorini, 2015) berpendapat bahwa kesulitan siswa dalam menyelesaikan soal cerita pada aspek pemahaman soal adalah kesulitan memahami apa maksud dari soal dan kesulitan siswa membedakan bangun/simbol dari apa yang diketahui. Hal ini fatal karena dalam PMRI, penggunaan konteks termasuk memahaminya bukan sebagai bentuk aplikasi suatu konsep melainkan sebagai titik awal pembangunan suatu konsep (Wijaya, 2012). Memahami masalah kontekstual adalah suatu yang sangat penting dalam pembelajaran yang menggunakan PMRI. Ahlfors (Wijaya, 2012) menyatakan ekstraksi konsep yang tepat dari suatu situasi konkrit, generalisasi terhadap kasus-kasus yang diobservasi, argumentasi induktif, argumentasi dengan analogy dan landasan intuitif dalam merumuskan suatu dugaan (conjecture) merupakan bentuk cara-cara matematis dalam berpikir. Akan tetapi, yang paling penting dari hal tersebut adalah ekstraksi konsep yang tepat dari suatu situasi konkrit. Menurut Wijaya (2012), suatu pengetahuan akan menjadi bermakna bagi siswa jika proses belajar melibatkan masalah realistic atau dilaksanakan dalam dan dengan suatu konteks. Ini berarti ketika siswa tidak mampu memahami masalah kontekstual maka siswa tidak memaknai pembelajaran. Kesulitan 7 dari 23 siswa dalam memahami masalah kontekstual pada angket, menunjukan bahwa pembelajaran tidak bermakna bagi mereka.

Menurut Wijaya (2012), untuk mengembangkan konteks yang perlu diperhatikan guru adalah memperhatikan pengertahuan awal yang dimiliki siswa. Pengetahuan awal karena dalam PMRI, keterkaitan antara konsep-konsep dalam matematika tidak bersifat parsial, melainkan memiliki keterkaitan. Dalam pembelajaran matematika berpendekatan PMRI yang telah dilaksanakan, Peneliti menggunakan materi SPLDV dan SPLTV. Materi tersebut merupakan materi yang membutuhkan pengetahuan awal berupa operasi bilangan bulat, pengetahuan non formal, dan pengetahuan lainnya yang mendukung proses pembelajaran. Ketidak mampuan siswa yang telah ditunjukan menunjukan bahwa siswa tidak menguasai materi yang telah diajarkan pada jenjang sebelumnya. Dalam pembelajaran yang berlangsung, guru dan peneliti tidak memperhatikan pengetahuan awal yang dimiliki siswa dalam membuat soal. Ketidakperhatian tersebut, membuat 23 siswa salah dalam menyelesaikan soal nomor 1 pada LKS 1.

Selain kesulitan memahami masalah kontekstual, siswa juga mengalami kesulitan membuat model matematika. Terdapat 4 siswa yang kurang mampu membuat model matematika dari masalah kontekstual pada materi SPLDV dan 6 siswa pada materi SPLTV dari total 23 siswa yang menjawab angket. Kesulitan membuat model matematika ditandai dengan siswa 
yang salah membuat model matematika dari masalah yang diberikan.

Ketelitian saat membuat model sangat diperlukan karena sangat menentukan untuk langkah berikutnya. Menurut Soedjadi (Kurniati, 2007) pada tahap ini siswa ditekankan untuk membuat model matematika yang sesuai dengan masalah yang diberikan. Pada aspek ini merupakan langkah yang paling penting karena akan berpengaruh pada tahap selanjutnya. Wijaya (2012) menyatakan hal yang senada dengan pendapat Soejadi yaitu dalam PMRI, penggunaan model menjadi jembatan dari pengetahuan dan matematika tingkat kongkrit menju pengetahuan matematika tingkat formal.

Kesulitan ini diduga karena ketidaktelitian siswa melihat perbedaan dari tiga variabel yang berbeda. Untuk meminimalisir kesalahan karena tidak teliti, dapat dilakukan dengan memperbanyak latihan. Hal tersebut sesuai dengan teori Koneksionisme yang dicetuskan oleh Thorndike tahun 1949. Salah satu hukum belajar menurut Throdike adalah hukum latihan yang mengimplikasikan bahwa semakin banyak berlatih maka seorang pembelajar akan semakin kuat, sebaliknya jika tidak dilatih maka ia akan semakin lemah (Tyas, 2016; Mayasari \& Afriansyah, 2016). Salah satu kelemahan PMRI berdasarkan pembelajaran yang telah dilaksanakan, untuk menyelesaikan satu soal diperlukan waktu kurang lebih 20 menit. Hal ini terjadi karena satu soal harus didiskusikan terlebih dahulu oleh kelompok, dan kemudian setiap kelompok harus mempresentasikan pekerjaan mereka di depan kelas demi menemukan strategi terbaik dalam pemecahan masalah. Soal yang dikerjakan siswa dalam LKK sangat tebatas. Jumlahnya hanya dua soal mengingat waktu yang terbatas untuk kegiatan pembelajaran. Sehingga dapat disimpulkan bahwa jumlah soal yang disajikan dalam pembelajaran sangat minim. Keterbatasan tersebut membuat siswa kurang berlatih mengerjakan soal.

\section{E. Kesulitan Siswa dalam diskusi}

Dalam pembelajaran, guru telah menggunakan pendekatan yang bervariasi dalam pembelajaran matematika. Dalam hal ini, guru menggunakan pendekatan PMRI. Dalam PMRI, guru menggunakan metode kooperatif melalui kegiatan diskusi. Penggunakan metode yang dipilih juga telah disesuaikan degan materi yang akan diajarkan. Dalam metode diskusi yang digunakan, siswa S-5 mengalami kesulitan karena terdapat siswa yang egois saat diskusi. Siswa tersebut tidak memberi ruang kepada anggota kelompok untuk memberikan pendapat. Hal ini sesuai pendapat Juniati (2017:3) yang mengemukakan salah satu kelemahan diskusi yaitu diskusi cenderung sering di dominasi oleh seorang anggota kelompok diskusi. Selain siswa S-5, siswa S-2 juga menceritakan kesulitannya dalam memimpin kelompok diskusi. Hal ini sesuai pendapat Juniati (2017) yang mengemukakan kelemahan lain dari diskusi yaitu dibutuhkan kemampuan berdiskusi 
dari para peserta agar dapat berpartisipasi secara aktif dalam diskusi. Jika anggota tidak aktif karena masalah pribadi, maka kegiatan diskusi tidak akan berjalan lancar.

Dalam pembelajaran yang telah berlangsung, guru menerapkan 5-6 orang dalam kelompok. Jumlah yang banyak ini tidak ideal. Seharusnya jumlah anggota dalam kelompok sebanyak 4 siswa. Ketika diskusi tidak efektif dilaksanakan maka mengakibatkan tidak ditemukan strategi pemecahan masalah terbaik. Akan tetapi, diskusi merupakan salah satu ciri PMRI. Kegiatan ini tidak dapat dihilangkan. Hal yang perlu dilakukan guru adalah mengefektifkan kegiaan diskusi melalui mengatur jumlah yang ideal dalam diskusi dan sebagainya.

\section{F. Kesulitan dalam Keterampilan Menghitung}

Keterampilan menunjuk pada sesuatu yang dilakukan seseorang. Jenis keterampilan matematika adalah proses dalam menggunakan operasi dalam penjumlahan, pengurangan, perkalian, dan pembagian. Kesulitan dalam operasi hitung dapat terjadi karena siswa melakukan kesalahan dalam mengoperasikan angka secara tidak benar. Ditemukan 4 siswa yang kurang teliti dalam mengerjakan SPLDV dan 6 siswa yang kurang teliti saat mengerjakan SPLTV dari jumlah keseluruhan siswa sebanyak 23 orang. Kesalahan mengoperasikan angka, ditemukan peneliti ketika siswa mengerjakan soal pada materi SPLDV. Kesalahan tersebut merupakan bentuk ketidaktelitian dalam menghitung.
Jemaris (Tyas,2016) berpendapat bahwa kesulitan yang dialami siswa yang kesulitan belajar matematika salah satunya adalah kelemahan dalam berhitung yang disebabkan salah membaca simbol dan mengoperasikan angka secara tidak benar. Untuk meminimalisir kesalahan karena tidak teliti, dapat dilakukan dengan memperbanyak latihan

Peneliti juga menemukan bahwa siswa mengabaikan tanda pengoperasian yang dipilih demi mendapat hasil yang benar terlebih khusus pada operasi dua persamaan yang menggunakan metode eliminasi. Meskipun jawaban akhirnya benar,tetap saja siswa salah diawal yang menimbulkan dugaan bahwa hasil kerja siswa merupakan sebuah plagiasi. Kesulitan siswa terjadi karena kecakapan dalam menghitung bilangan bulat masih kurang. Sholekah,dkk (2017) mengatakan matematika memang merupakan ilmu yang saling berkaitan. Selain itu, guru perlu mengoptimalkan kemampuan berhitung setiap siswa agar proses pembelajaran dan penyelesaian masalah matematika yang umumnya berkaitan dengan perhitungan dapat dilakukan karena akan lebih mudah diselesaikan apabila mempunyai kemampuan numerik yang tinggi (Gunur, Ramda, \& Makur, 2018). Dalam proses pembelajarannya, materi matematika yang satu mungkin merupakan prasyarat bagi materi yang lainnya, atau konsep yang satu diperlukan untuk menjelaskan konsep yang lainnya. Dalam PMRI, pengetahuan yang dimiliki siswa baik yang didapat dari 
lembaga formal ataupun nonformal menjadi landasan bagi siswa dalam mengkonstruksikan pengetahuan.

\section{G. Kesulitan Memecahkan Masalah}

Hasil angket tentang kesulitan memecahkan masalah dan hasil pekerjaan siswa pada soal cerita menunjukkan bahwa siswa tidak terbiasa menentukan langkah pemecahan masalah dengan tepat meskipun beberapa pekerjaan mereka benar. Sebanyak 3 siswa tidak menulis keterangan yang ditanya dan sebanyak 7 siswa yang tidak menulis keterangan diketahui. Selain itu 5 siswa tidak menulis petunjuk tiap persamaan dan ditemukan juga siswa yang tidak menemukan variabel yang ditanya. Ditemukan juga terdapat 13 siswa yang tidak memeriksa kembali kebenaran terhadap jawaban yang didapat pada materi SPLDV dan 12 siswa pada materi SPLTV.

Pemecahan masalah adalah aplikasi dari konsep dan keterampilan. Pengembangan indikator dari pemecahan masalah ditunjukkan dengan siswa tidak melanjutkan pekerjaan dalam menyelesaikan soal, termasuk melewatkan beberapa langkah penyelesaian dalam pekerjaan siswa. Menurut Polya (Ruhayana,2016), pemecahan masalah terdiri dari: (1) Memahami Masalah yang didalamnya terdapat unsur-unsur seperti memuat apa yang diketahui, apa yang ditanya, apa saja informasi yang ada; (2) Membuat rencana untuk menyelesikan masalah yang didalamnya membuat pola, tabel, atau gambar, dan juga menentukan rumus atau metode; (3) Melaksanakan rencana yang didalamnya terdapat strategi pemecahan masalah; (4) Memeriksa ulang jawaban demi mencocokan hasil sesuai yang ditanyakan, mengiterpretasi jawaban yang diperoleh, mengidentifikasi cara lain untuk mendapatkan penyelesaian masalah, dan juga mengidentifikasi jawaban lain yang memenuhi.

Dalam pekerjaan siswa, peneliti tidak menemukan siswa yang memeriksa kembali jawaban. Selain itu, langkahlangkah pengerjaan soal siswa bervariatif. Dalam penelitian ini, ciri khas PMRI dapat dilihat dari pengembangan model dan strategi yang berbeda oleh setiap siswa dipengaruhi oleh perbedaan pengalaman dan interpretasi siswa (Wijaya, 2012). Tetapi, langkah-langkah yang diberikan Polya merupakan langkah pemecahan masalah yang tepat dan sistematis. Hal ini menjadi kelemahan guru dalam pembelajaran, di mana guru tidak memberikan langkah-langkah sesuai pendapat Polya. Pekerjaan siswa dibuat hanya berdasarkan pengalaman siswa.

\section{H. Kesulitan membuat kesimpulan}

Dalam pertemuan pertama, setelah siswa mempresentasikan pekerjaan kelompok, siswa diarahkan untuk kembali ke posisi semula. Guru tidak mengajak siswa untuk menarik kesimpulan dari pekerjaan siswa. Hal yang sama terjadi ketika pada pertemuan ke dua, siswa hanya mendengar kesimpulan yang dipaparkan guru di depan kelas. Kelalaian guru yang tidak mengajak siswa untuk berpartisipasi 
dalam pembuatan kesimpulan membuat siswa tidak mampu menarik kesimpulan dari materi yang diajarkan guru selama dua pertemuan.

\section{Penutup}

Berbagai jenis kesulitan siswa telah kami temukan di dalam penelitian ini. Kesulitan pada kegiatan pendahuluan terjadi kegiatan apersepsi. Siswa memiliki kesulitan pada kegiatan apersepsi ditunjukan dengan siswa tidak menjawab pertanyaan guru. Kesulitan pada kegiatan inti yang pertama adalah kesulitan siswa dalam memahami dan menjawab pertanyaan dalam permainan. Kesulitan memahami konsep terutama pada memahami masalah kontekstual dan membuat model matematika. Kesulitan lain yang terjadi adalah kesulitan saat diskusi. Kesulitan dalam menemukan strategi terbaik yang dialami siswa meliputi kesulitan keterampilan menghitung khususnya pada penerapan tanda operasi dan ketelitian dalam mengoperasikan angka, dan juga kesulitan memecahkan masalah yang ditandai dengan ketidakmampuan menulis langkah penyelesaian soal cerita secara tepat seperti tidak membuat perencanaan dan tidak memeriksa kembali pekerjaan.

\section{UCAPAN TERIMA KasIH}

Terima kasih kepada Program Studi Pendidikan Matematika Unika Santu Paulus Ruteng yang berkenan mendukung terlaksananya penelitian ini. Terima kasih juga kepada Kepala Sekolah dan Guru Matematika SMK Karya Ruteng, Kabupaten Manggarai, NTT yang memfasilitasi pelaksanaan penelitian ini.

\section{Daftar Pustaka}

Afriansyah, E. A., \& Dahlan, J. A. (2017). Design Research in Fraction for Prospective Teachers. the 5th SEA-DR (South East Asia Development Research) International Conference 2017 (SEADRIC 2017). Advances in Social Science, Education, 100, 91-97.

Badruddin, E. (2013). Implementasi Pendekatan Realistik Pasa Pembelajaran Operasi Bilangan Real Untuk Meningkatkan Hasil Belajar Siswa SMK Negeri 5 Telkom Banda Aceh. Jurnal Peluang, 2(1).

Edo, S. M., \& Samo, D. D. (2017). Lintasan Pembelajaran Pecahan Menggunakan Matematika Realistik Konteks Permainan Tradisional Siki Doka. Mosharafa: Jurnal Pendidikan Matematika, 6(3), 311-322.

Gunur, B., Makur, A. P., \& Ramda, A. H. (2018). Hubungan Antara Kemampuan Numerik Dengan Kemampuan Pemecahan Masalah Matematis Siswa Di Pedesaan. MaPan, 6(2), 148-160. DOI: 10.24252/mapan.2018v6n2a2

Hayati, A. N. (2016). Pengaruh Kebiasaan Belajar dan Perhatian Orang Tua Terhadap Hasil Belajar Kognitif Matematika. Jurnal Pendidikan Guru Sekolah Dasar UNY, 13(3).

Juniati, E. (2017). Peningkatan Hasil Belajar Matematika Melalui Diskusi kelompok Pada Siswa Kelas VI SD. Jurnal Pendidikan dan Kebudayaan Scholaria, 7 (3). 
Mayasari, Y., \& Afriansyah, E. A. (2016). Kemampuan Koneksi Matematis Siswa melalui Model Pembelajaran Berbasis Masalah. Jurnal Riset Pendidikan, 2(1), 27-44.

Nursyahidah, F., Saputro, B. A., Albab, I. U., \& Aisyah, F. (2020). Pengembangan Learning Trajectory Based Instruction Materi Kerucut Menggunakan Konteks Megono Gunungan. Mosharafa: Jurnal Pendidikan Matematika, 9(1), 47-58.

Ruhayana. (2016). Analisis Kesulitan Siswa Dalam Pemecahan Masalah Matematika. Jurnal Computech dan Bisnis, 10(2).

Sopian, Y., \& Afriansyah, E. A. (2017). Kemampuan Proses Pemecahan Masalah Matematis Siswa Melalui Model Pembelajaran Creative Problem Solving dan Rerource Based Learning. Jurnal Elemen, 3(1), 97-107.

Soviawati, E. (2011). Pendekatan Matematika Realistik Untuk Meningkatkan Kemampuan Berfikir Siswa di Tingkat Sekolah Dasar. https://www.scribd.com/doc/79000896 /. diakses pada 15 Februari 2018.

Sugyono. (2012). Metode Penelitian Pendidikan. Bandung: Penerbit Alfabeta. Tyas, N. M. (2016). Analisis faktor penyebab kesulitan belajar matematika kelas IV SDN di Kecamatan Ungaran Barat. Skripsi. Universitas Negri Semarang.http://lib.unnes.ac.id/24893/ 1/1401412428.pdf pada 24 Februari 2018.

Waskitoningtyas, R. S. (2011). Analisis Kesulitan Belajar Matematika Siswa Sekolah Dasar Kota Balikpapan pada materi satuan waktu tahun ajaran 2015/2016. Jurnal IImiah Pendidikan Matematika, 6(1).
Wijaya, A. (2012). PMR Suatu Alternatif Pendekatan Pembelajaran Matematika. Yogyakarta: Graha Ilmu.

Yusri, A. Y., \& Sari, M. (2017). Profil Pemahaman Konsep Nilai Tempat Ditinjau Dari Kemampuan Awal Matematika Pada Siswa Kelas III SDN 133 Takalala Soppeng. Mosharafa: Jurnal Pendidikan Matematika, 6(1), 141-152.

\section{Riwayat Hidup PenUlis Pius Eko P Cahirati, S.Pd.}

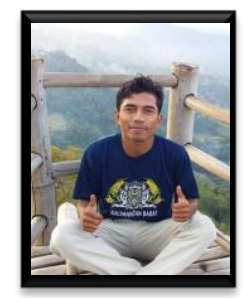

Lahir di Manggarai, 20 Agustus 1995. Mahasiswa di Program Studi Pendidikan Matematika STKIP Santu Paulus Ruteng. Studi S1 Program Studi Pendidikan Matematika STKIP Santu Paulus Ruteng lulus tahun 2019.

\section{Alberta Parinters Makur, S.Si, M.Pd.}

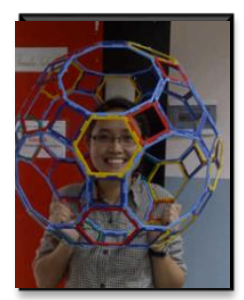

Lahir di Ende, 9 Mei 1988. Staf pengajar di Program Studi Pendidikan Matematika Unika Santu Paulus Ruteng. Studi S1 Matematika Universitas Indonesia, Depok, lulus tahun 2009 dan S2 Pendidikan Matematika Universitas Negeri Jakarta, lulus tahun 2014.

Sebastianus Fedi, M.Pd.

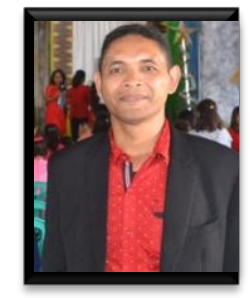

Lahir di Heso, 27 Desember 1979. Penulis menyelesaikan S1 Program Studi Matematika di Universitas Nusa Cendana pada tahun 2006. Menyelesaikan S2 Pendidikan Matematika di UNDIKSHA Singaraja tahun 2014. 